\title{
Federal-State Conflicts in the Field of Habeas Corpus
}

\author{
Melvin E. Beverly*
}

\begin{abstract}
A
QUESTION that has long plagued the federal judiciary is when a lower

federal court should entertain an application for habeas corpus by a state prisoner. The thought has been expressed that when a federal district court releases a state prisoner on habeas corpus it is in effect reviewing or reversing a final judgment of a state's highest court; ${ }^{1}$ and it has been stated many times that only the Supreme Court of the United States should so reverse or review these final judgments. ${ }^{2}$ Only recently has the opinion been voiced that a federal court is not reviewing a state judgment when it entertains a petition by a state prisoner, but is merely applying the "supreme Law of the Land."
\end{abstract}

It has been recognized that the exercise of the power of the federal courts to discharge state prisoners where they are held in custody in violation of their rights under the Constitution or laws of the United States is within the sound discretion of these courts. ${ }^{4}$ It has also been recognized that " $[t]$ hat discretion should be exercised in the light of the relation existing between state and federal courts under our dual form of government, which relation should not be disturbed by unnecessary conflicts between state and national tribunals that are equally bound to guard constitutional rights." The opinion of Justice Frankfurter in Brown v. Allen laid down six "standards or directions that should govern the District Judges in the disposition of applications for habeas corpus by prisoners under sentence of State courts." "These standards probably represent the views of a majority of the Court, ${ }^{7}$ and if followed should do much to prevent any "un-

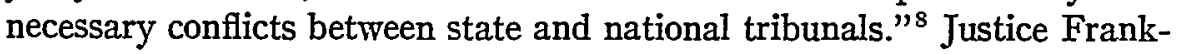

* Member, San Francisco Bar.

1 Report of the Conference of the Chief Justices of the States, 25 ST. Gov'T 249-250 (1952); Parker, Limiting the Abuse of Habeas Corpus, 8 F.R.D. 171, 173 (1948); Stonebreaker v. Smyth, 163 F.2d 498, 499 (4th Cir. 1947).

2 Darr v. Burford, 339 U.S. 200, 217 (1950); Report of the Conference, supra note 1; Parker, supra note 1.

3 Opinion of Frankfurter, J., in Brown v. Allen, 344 U.S. 443, 510 (1953) ; see also Schechtman v. Foster, 172 F.2d 339 (2d Cir. 1949), cert. denied, 339 U.S. 924 (1950).

4 Ex parte Royall, 117 U.S. 241 (1886).

5 Johnson v. Wilson, 131 F.2d 1, 2 (5th Cir. 1942).

6 Brown v. Allen, supra note 3 , at 501 .

TWhile not technically a "holding," this portion of Justice Frankfurter's opinion was agreed with in substance by Justices Black and Douglas, and the "propriety" of these standards was "recognized" by Justices Burton and Clark.

8 Johnson v. Wilson, supra note 5 
furter's standards may be summarized as follows: (1) a prima facie case must be made out; (2) the state remedies must be exhausted; (3) the record of the state proceedings, when adequate, should be used by the district courts in determining the facts; (4) findings of fact by the state courts may be taken as true unless a vital flaw in the process of ascertaining such facts is found to exist; (5) an independent judgment must be exercised by the districts courts on "mixed questions" of law and fact; and (6) the federal judge may take into account prior denials of relief by other federal courts.

This article will discuss the background of each of these standards and will attempt to point out the effect of each upon a prisoner's petition for a writ in the federal courts. No attempt will be made to discuss the substantive grounds upon which the writ may be granted or denied.

\section{Prima Facie Case}

The requirement that a prima facie case be made out is self-evident. As in any other litigation, if the party with the burden of pleading does not state a claim upon which relief can be granted, the cause will be dismissed. ${ }^{\circ}$ Since a judgment on a petition for habeas corpus is not res judicata, ${ }^{10}$ a dismissal cannot prejudice the petitioner's right to seek relief subsequently on a new petition.

\section{Exhaustion of State Remedies}

It is now settled that state remedies, if any there be, must be exhausted before a state prisoner may seek habeas corpus in the federal courts. ${ }^{11}$ The revisers stated that this section was merely declaratory of the law as declared by the Supreme Court ${ }^{12}$ in Ex parte Hawk.$^{13}$ Because of the Hawk case requirement that a state prisoner ordinarily must apply to the Supreme Court for certiorari before seeking relief in the federal courts, it has recently been held that the seeking of certiorari is a part of the state remedies under Section 2254. ${ }^{14}$

\footnotetext{
9 FED. R. CIV. P. 12 (b).

${ }^{10}$ Salinger v. Loisel, 265 U.S. 224 (1924).

1128 U.S.C. \&2254 (Supp. 1952):
}

An application for a writ of habeas corpus in behalf of a person in custody pursuant to the judgment of a State court shall not be granted unless it appears that the applicant lias exhausted the remedies available in the courts of the State, or that there is either an absence of available State corrective process or the existence of circumstances rendering such process inefiective to protect the rights of the prisoner.

An applicant shall not be deemed to have exhausted the remedies available in the courts of the State, within the meaning of this section, if lie has the riglit under the law of the State to raise, by any available procedure, the question presented.

1228 U.S.C. § 2254 (reviser's note).

13321 U.S. 114 (1944).

14 Darr v. Burford, supra note 2, at 210. 
Very few cases have held that such extraordinary circumstances existed as to warrant a district court's entertaining a writ in the absence of an attempt to have the Supreme Court review the refusal of a state remedy upon certiorari. Darr v. Burford made it clear that these cases are very exceptional but that they do exist. ${ }^{15}$ Examples of such cases are where the state remedy proves inadequate or ineffective or is nonexistent; ${ }^{16}$ where the Supreme Court had twice denied certiorari previously on the same questions; ${ }^{17}$ where prison rules denied a prisoner access to the courts except through an attorney and the prisoner had neither attorney nor funds with which to employ one; ${ }^{18}$ where the sentence would be fully served before certiorari could be acted upon; ${ }^{19}$ or where the state authorities had delayed in acting upon the prisoner's attempts to secure executive clemency and judicial relief until shortly before his scheduled execution. ${ }^{20}$ In Wade $v$. Mayo, the Supreme Court had indicated that the fact that a petitioner had not sought certiorari should not bar a district court fron exercising its discretion as to whether to entertain a petition..$^{21}$ However, this aspect of Wade v. Mayo was expressly disapproved by Darr v. Burford, except in those cases where exceptional circumstances are present. ${ }^{22}$

Extradition cases were once thought to present a special problent. The Third Circuit held that where a prisoner was seeking to avoid extradition, the doctrine of exhaustion of remedies was inapplicable. ${ }^{23}$ Other circuits held otherwise, requiring a petitioner to exhaust his remedies both in the state seeking extradition and in the state of arrest. ${ }^{24}$ The Supreme Court apparently has recognized that where a prisoner is threatened with immediate extradition and alleges violations of federal rights, an extraordinary case within the meaning of Darr v. Burford is presented; ${ }^{25}$ but recently it

\footnotetext{
10 Supra note 2, at 210.
}

10 United States ex rel. White v. Walsh, 174 F.2d 49, 58 (7th Cir.), rev'd without opinion, 338 U.S. 804 (1949); Potter v. Dowd, 146 F.2d 244, 246 (7th Cir. 1944).

17 Baconı v. Sullivan, 194 F.2d 166, 167 (5th Cir. 1952).

18 United States ex rel. Rooney v. Ragen, 158 F.2d 346 (7th Cir. 1947).

10 United States ex rel. White v. Walsh, supra note 16 , at 59.

20 Thomas v. Duffy, 191 F.2d 360 (9th Cir. 1951).

21334 U.S. 672 (1948).

22 Supra note 2. The Seventh Circuit recently relied upon Wade v. Mayo in determining the merits of a petition notwithstanding that no application for certiorari had been made (the decision was adverse to the petitioner), United States ex rel. Scott v. Babb, 199 F.2d 804 (7th Cir. 1952).

23 Johnson v. Dye, 175 F.2d 250, 257 (3d Cir.), rev'd per curiam, 338 U.S. 864 (1949) (citing Ex parte Hawk, supra note 13, thus indicating that the Supreme Court thought that the doctrine was applicable).

24 Ross v. Middlebrooks, 188 F.2d 308 (9th Cir. 1951) ; Davis v. O'Connell, 185 F.2d 513 (8th Cir. 1950), cert. denied, 341 U.S. 941 (1951) ; Morgan v. Horrall, 175 F.2d 404 (9th Cir.), cert. denied, 338 U.S. 827 (1949).

25 Frisbie v. Collins, 342 U.S. 519 (1952), approving findings of extraordinary circumstances in Collins v. Frisbie, 189 F.2d 464 (6th Cir. 1951). 
held that an escaped prisoner could not question the justice of his incarceration by a habeas corpus proceeding in the district court for the state of asylum. ${ }^{26}$

In White v. Ragen ${ }^{27}$ the Supreme Court indicated that where a state's highest court has denied a petition for relief without opinion and without holding a hearing, it would be assumed that that court acted on a nonfederal ground and, since it would be automatically rejected, certiorari would not be required as a part of the exhaustion process. ${ }^{28}$ Two circuits have refused to apply this rule on the grounds that ordinarily the writ of habeas corpus is the proper manner in which to raise federal questions in the state, and hence the federal question must have been considered and rejected; ${ }^{29}$ or that White v. Ragen was based upon a peculiar Illinois rule preventing that state's supreme court from entertaining petitions raising fact questions; ${ }^{30}$ or that Darr v. Burford ruled to the contrary and that subsequently the Court had adopted the policy of vacating the state court's judgment in order that the prisoner night seek a more definite determination from the state court. ${ }^{31}$ In neither of the cases relied upon by the Ninth Circuit $^{32}$ did the Supreme Court actually grant certiorari. ${ }^{33}$ All of these cases were prior to the recent decision of the Supreme Court in Stembridge v. Georgi $a^{34}$ in which the Court refused certiorari on direct review because the state court opinion might have been based on an adequate state ground. Darr v. Burford recognized that there were exceptions to the rule that ordinarily a petition for certiorari is a part of the exhaustion process ${ }^{35}$ and cited White $v$. Ragen as representing one of these exceptional situations. ${ }^{30}$

It is this writer's opinion that where a state's highest court denies relief without explanation, an application for certiorari should not be required. Such an application will probably be futile anyway, because the Supreme

26 Sweeney v. Woodall, 344 U.S. 86 (1952).

27324 U.S. 760 (1945).

28 Stembridge v. Georgia, 343 U.S. 541, 546 (1952); see also Woods v. Nierstheimer, 328 U.S. 211, 216 (1946).

29 Pennsylvania ex rel. Billman v. Burke, 170 F.2d 413 (3d Cir. 1948) (the State court in a per curiam decision had refused to consider the writ on the ground that it did not bave the power to interfere with the quantum of a sentence where the sentence was within the statutory maximum).

30 Gordon v. Scudder, 163 F.2d 518 (9th Cir.), cert. denied, 332 U.S. 830 (1947).

31 Darcy v. Heinze, 194 F.2d 664 (9th Cir.), cert. denied, 343 U.S. 943 (1952), citing Jennings v. Illinois, 342 U.S. 104 (1951) and Dixon v. Duffy, 342 U.S. 33 (1951) (continued until petitioner could obtain definitive statement from the State court), vacated and remanded, 343 U.S. 393 (1952).

32 Supra note 31 .

33 Jennings v. Ilinois; Dixon v. Duffy, both sufra note 31.

34 Supra note 28.

35 Supra note 2, at 210 .

36 Id. at 210, n.29. 
Court will deny it in most instances. In no way would retaining the requirement of certiorari in these circumstances aid in the prevention of conflicts between the state and federal systems. This does not mean, however, that a petition for certiorari will not be required where the purported state ground is unsubstantial or insufficient. In such a case the Supreme Court will assume that the decision was based upon the federal ground presented by the petition and will consider whether the question is of sufficient importance to warrant the granting of certiorari. ${ }^{37-38}$

Apart from the problem of whether one must seek certiorari is the problem presented where more than one state remedy is available. Must the prisoner seek relief through each of the alternative remedies, including several trips to the Supreme Court for certiorari, before he may seek relief from the federal courts? Several circuits have held that this is the case, ${ }^{39}$ and the language of the second paragraph of Section 2254 would seem so to require..$^{40}$ The chairman of the committee which drafted this section even went so far as to declare that where a judgment on a remedy was not res judicata in the state courts, the petitioner could never get into the federal courts. ${ }^{11}$ This view was adopted by the Fifth Circuit. ${ }^{42}$

In 1948, before Section 2254 became effective, the Supreme Court decided that pursuance of one of two alternative state remedies was a sufficient exhaustion. ${ }^{43}$ Several circuits, relying on the language of the statute, did not follow this case..$^{44}$ All of the circuits in which the question arose agreed that the fact the question had been raised on a direct appeal did not excuse the petitioner from seeking relief under the state's collateral remedies. ${ }^{45}$ In taking the attitude that more than one avenue of relief must be followed, the courts were not achieving the salutary purpose of determining federal issues as rapidly as possible. Quite often the only result of such a course

37-38 Williams v. Kaiser, 323 U.S. 471, 477 (1945).

39 Porch v. Cagle, 199 F.2d 865 (5th Cir. 1952) ; United States ex rel. Barrigar v. Robinson, 189 F.2d 766 (7th Cir. 1951) ; Bacom v. Sullivan, 181 F.2d 177 (5th Cir. 1950); United States ex rel. Monsky v. Warden, 163 F.2d 978 (2d Cir. 1947), cert. denied, 332 U.S. 848 (1948); McCrea v. Jackson, 148 F.2d 193 (6th Cir. 1945).

40 Supra note 11.

41 Parker, supra note 1.

42 Nusser v. Aderhold, 164 F.2d 127 (5th Cir. 1947). In a dictuin the Ninth Circuit indicated that it did not hold to this view, Ekberg v. McGee, 191 F.2d 625 (9th Cir. 1951), amended, 194 F.2d 178 (9th Cir. 1952), cert. granted, 342 U.S. 952 (1952), dismissed as moot, 343 U.S. 970 (1952); but cf. Betts v. Brady, 316 U.S. 455, 461 (1942).

43 Wade v. Mayo, supra note 21 , at 676 .

44 Porch v. Cagle; United States ex rel. Barrigar v. Robimson; Bacoin v. Sullivan, supra note 39. Other circuits did follow Wade v. Mayo, United States ex rel. Master v. Baldi, 198 F.2d 113 (3d Cir. 1952); Canada v. Jones, 170 F.2d 606 (8th Cir. 1948).

45 McRea v. Jackson, supra note 39; United States ex rel. De Frates v. Ragen, 181 F.2d 1001 (7th Cir. 1950) ; Carr v. Burford, 188 F.2d 159 (10th Cir. 1951) ; Bacom v. Sullivan, supra note 17. 
was to delay the execution of a state judgment and thus to give rise to further criticism of the federal process as it relates to state prisoners.

The Supreme Court decided this issue definitively in a recent decision, Brown v. Allen. ${ }^{46}$ There it was held not only that the attempt at one of several alternate state collateral remedies would suffice, but also that if the question were raised by direct review (appeal in the state courts and denial of certiorari by the Supreme Court) there would be no necessity to attempt the state collateral remedies before coming into the federal courts. It is not supposed, however, that this means an attempt at an incorrect method of relief will suffice. ${ }^{4 T}$. The method attempted must be one which will afford relief from the wrong claimed.

The Fourth and Seventh Circuits have held that where there is a change of law, either legislative or judicial, subsequent to the attempt to gain relief in the state courts, the new law inust be presented to the state courts before the federal courts will grant relief. 48 Since a question should be presented at least once to the state courts, this rule should remain in effect. It is a worthy rule which grants the states an adequate opportunity to apply federal law to their own judgments before a federal court steps in.

Section 2254 recognizes that where "there is either an absence of available state corrective process or the existence of circumstances rendering such process ineffective to protect the rights of the prisoner," there is no necessity to show an exhaustion of state remedies. ${ }^{40}$ In a very few cases the courts have found that such circumstances exist. These are: that the state court rejected papers filed by a prisoner because they were in improper form, and would not appoint an attorney to aid him in the preparation of papers in the proper form (Indiana) $;^{50}$ that the time for seeking the relief had expired (Illinois); ${ }^{51}$ that the sentence would have been served before the state reunedy could be exhausted (Illinois); ${ }^{52}$ that prison officials had

46 Supra note 3.

47 See United States ex rel. Velasco v. Ragen, 158 F.2d 87 (7th Cir. 1946); New York ex rel. Whitman v. Wilson, 318 U.S. 688 (1943).

48 United States ex rel. Haniby v. Ragen, 178 F.2d 379 (7th Cir.), cert. denied, 339 U.S. 905 (1950); United States ex rel. Peters v. Ragen, 178 F.2d 377 (7th Cir. 1949), cert. denied, 338 U.S. 944 (1950); Stonebreaker v. Smyth, supra note 1; see New York ex rel. Whitman v. Wilson, supra note 47; Young v. Ragen, 337 U.S. 235 (1949).

49 Supra note 11.

50 Potter v. Dowd, supra note 16; but not the mere fact that the state court refused to permit the petition to be filed in forma pauperis, Barton v. Smith, 162 F.2d 330 (9th Cir. 1947); United States ex rel. Auld v. Warden, 187 F.2d 615 (3d Cir. 1951). Contra: Dolan v. Alvis, 186 F.2d 586 (6th Cir. 1951).

51 United States ex rel. Rooney v. Ragen, supra note 18. Contra: Barton v. Smith, supra note 50; McGarty v. O'Brien, 180 F.2d 987 (1st Cir.), cert. denied, 339 U.S. 966 (1950); United States ex rel. Auld v. Warden, supra note 50.

52 United States ex rel. White v. Walsh, supra note 16 (also decided on the ground that it was doubtful whether any state remedy was available). 
prevented a timely application for relief by holding up papers (Indiana); $;^{53}$ and that the prisoner, who had been convicted under New York's "second offender" statute, could not attack the first conviction in New York because that state required the attack to be made in the sentencing court, and he could not attack it in the state of the first judgment (Wisconsin) because that state required that he be in the custody of its officials. ${ }^{54}$ Only one case has found a complete absence of corrective process (in Washmgton), ${ }^{55}$ and in a later case the same court found that the defect had been cured by subsequent statutory amendments. ${ }^{56}$

The burden is on the prisoner to show the absence or ineffectiveness of the state remedy. ${ }^{j 7}$ The prisoner must actually attempt to obtain relief through the state process in order to show such absence or ineffectiveness. ${ }^{58}$ Thus, the fact that the state remedy is possibly, arguably, or even probably nonexistent or ineffective is not sufficient. It must positively be shown that such is the case. ${ }^{50}$

Assuming the presence and effectiveness of a state remedy, one may still be denied relief in the state courts because the question is one which could have been raised at the trial resulting in the conviction or on appeal therefrom. Many circuits have adopted the view that where the question could have been so raised, the prisoner cannot raise it by habeas corpus. ${ }^{60}$ The Second Circuit, in a questionable decison, held that a failure to raise the question by a petition for certiorari from an unsuccessful state appeal would prevent the prisoner from raising it by a petition for federal habeas corpus. ${ }^{.1}$ These cases have relied on a long line of Supreme Court cases

63 United States ex rel. Cook v. Dowd, 180 F.2d 212 (7th Cir. 1950), vacated to allow State authorities a reasonable time in which to cure the defect, Dowd v. United States ex rel. Cook, 340 U.S. 206 (1951).

54 United States ex rel. Turpin v. Snyder, 183 F.2d 742 (2d Cir. 1950).

55 Hampson v. Sinith, 153 F.2d 417 (9th Cir. 1945), cert. denied, 328 U.S. 850 (1946).

56 Huffman v. Smith, 172 F.2d 129 (9th Cir. 1949).

67 Buchanan v. O'Brien, 181 F.2d 601 (Ist Cir. 1950).

68 Whalen v. Frisbie, 185 F.2d 607 (6th Cir. 1950), cert. denied, 341 U.S. 911 (1951); Mason v. Smith, 162 F.2d 336 (9th Cir. 1947); Hampson v. Smith, 162 F.2d 334 (9th Cir. 1947) ; Barton v. Smith, supra note 50; Hawk v. Jones, 160 F.2d 807 (8th Cir.), cert. denied, 332 U.S. 779 (1947). See also the opinion of Justice Frankfurter in Brown v. Allen, supra note 3 at 502 .

50 Barton v. Smith, supra note 50.

co Harris v. Swenson, 199 F.2d 269 (4th Cir. 1952); Daniels v. Allen, 192 F.2d 763 (4th Cir. 1951), aff'd sub nom. Brown v. Allen, supra note 3 ; Coggins v. O'Brien, 188 F.2d 130 (1st Cir. 1951) ; United States ex rel. Rheim v. Foster, 175 F.2d 772 (2d Cir. 1949), cert. denied, 338 U.S. 857, 888 (1949) ; United States ex rel. Carr v. Martin, 172 F.2d 519 (2d Cir. 1949); United States ex rel. Johnson v. Ragen, 171 F.2d 630 (7th Cir. 1948), cert. denied, 336 U.S. 927 (1949); Baker v. Utecht, 161 F.2d 304 (8th Cir), cert. denied, 331 U.S. 856 (1947); United States ex rel. Rogalski v. Jackson, 146 F.2d 251 (2d Cir. 1944), cert. denied, 324 U.S. 873 (1945).

B1 United States ex rel. Rogalski v. Jackson, 146 F.2d 251 (2d Cir. 1944), cert. denied, 324 U.S. 873 (1945). This position was later abandoned, United States ex rel. Morrison v. Foster, 175 F.2d 495, 497 (2d Cir. 1949). 
holding that the writ of habeas corpus may not be used as a substitute for an appeal or a writ of error, ${ }^{62}$ and that a federal constitutional right may be waived. ${ }^{63}$

The rule that a failure to raise by direct attack bars habeas corpus is not absolute. Where a question may be raised by appeal or by the use of some collateral state remedy, exhaustion of the state collateral remedy will suffice under the alternative remedies theory. ${ }^{\circ 4}$ And where a substantial claim of federal right goes to the very foundation of a proceeding, the fact that the question was not urged at the trial is not fatal. ${ }^{\text {os }}$

If a prisoner has failed to exhaust his state remedies, is the federal court thus deprived of its jurisdiction to hear an application for a writ of habeas corpus? The statute does not seem so to deprive the court of jurisdiction, ${ }^{\infty}$ but provides merely that an application for a writ "shall not be granted" unless the state remedies have been exhausted. ${ }^{67}$ However, several circuits have held or indicated that the district court has no jurisdiction to entertain an application where the state remedies have not been exhausted. ${ }^{\text {cs }}$ Others have held that the court has jurisdiction but should not ordinarily exercise it. ${ }^{69}$ The latter view is clearly the more correct in that it takes into account those extraordinary situations where the writ may be granted notwithstanding a failure to exhaust the remedies, and this appears to be the

62 Sunal v. Large, 332 U.S. 174, 182 (1947); Yakus v. United States, 321 U.S. 414, 444 (1944) ; Woolsey v. Best, 299 U.S. 1 (1936) ; United States ex rel. Kennedy v. Tyler, 269 U.S. 13 (1925) ; Goto v. Lane, 265 U.S. 393, 409 (1924); Riddle v. Dyche, 262 U.S. 333 (1923).

63 Adams v. United States ex rel. McCann, 317 U.S. 269 (1942) (waiver at trial) ; Frank v. Mangum, 237 U.S. 309, 343 (1915) (waiver by not raising on appeal).

64 Wade v. Mayo, supra note 21, at 677-678; United States ex rel. Master v. Baldi, supra note 43.

65 Johnson v. Zerbst, 304 U.S. 458 (1938) (waiver nust be intelligent); Moore v. Denusey, 261 U.S. 86 (1923) (mob domination); United States ex rel. Cook v. Dowd, supra note 53 (prison rules prevented petitioner's making a timely appeal), reversed and remanded to give state courts an opportunity to give petitioner an adequate appeal, Dowd v. United States ex rel. Cook, supra note 53; Williams v. Kaiser, supra note 37, at 477 (wrongful deprivation of counsel prevented an appeal from being taken).

6028 U.S.C. $\$ 2254$, supra note 11.

67 United States ex rel. White v.Martin, 197 F.2d 147 (2d Cir. 1952); United States ex rel. Velasco v. Ragen, supra note 47; Mllinois ex rel. Davidson v. Bennett, 153 F.2d 271 (7th Cir. 1946).

68 Fouquette v. Bernard, 198 F.2d 860 (9th Cir. 1952), cert. denicd, 345 U.S. 912 (March 9, 1953); United States ex rel. Carr v. Martim, supra note 60 (semble); Hawk v. Jones, supra note 58; Canada v. Jones, supra note 44; United States ex rel. Ross v. Nierstheimer, 159 F.2d 994 (7th Cir. 1947) ; Makowski v. Benson, 158 F.2d 158 (6th Cir. 1946), cert. denied, 330 U.S. 823 (1947); United States ex rel. McCarthy v. Ragen, 153 F.2d 609 (7th Cir. 1946).

60 Duffy v. Wells, 201 F.2d 503, 504 (9th Cir. 1952); United States ex rel. Scott v. Babb, supra note 22 ; Coggins v. O'Brien, supra note 60; Plaine v. Burford, 180 F.2d 724 (10th Cir.), cert. denied, 339 U.S. 925 (1950) ; United States ex rel. Marshall v. Snyder, 160 F.2d 351 (2d Cir. 1947) ; Lyon v. Harkness, 151 F.2d 731 (1st Cir. 1945), cert. denied, 327 U.S. 782 (1946). 
view taken by the Supreme Court. ${ }^{70}$ Further support for this view is found in Sharpe v. Buchanan, ${ }^{71}$ where the district court had dismissed a petition because the state remedies had not been exhausted ${ }^{72}$ and the court of appeals affirmed this holding. ${ }^{73}$ While a petition for certiorari was pending before the Supreme Court, the petitioner sought and was refused relief in the state courts, thereby exhausting his state remedies. The Supreme Court remanded the cause to the court of appeals for such further proceedings as that court deemed appropriate, rather than requiring the petitioner to start all over again.

The rule requiring exhaustion of state remedies is designed to prevent interference by federal courts with the orderly administration of justice in the state courts. ${ }^{i 4}$ As developed by the cases, this rule requires that a state prisoner must first give the state courts an opportunity to rule on his federal questions. If the state will not or can not act on this opportunity, then the prisoner is entitled to have a federal court determine the validity of his claim-as a federal court applying federal law and not as an appellate tribunal reviewing the determination of the state court. ${ }^{75}$ In so applying federal law, the question arises as to what effect should be given to state court proceedings.

\section{Use of the Record of State Court Proceedings}

Assuming that a prima facie case has been made out and that the requirement of exhaustion of state remedies has been satisfied, the question next facing the court is how to ascertain the facts. Should a plenary hearing be held or may the record of proceedings before the state courts be used? Of course, where the record of state court proceedings is filed with the court, it becomes a part of the files in the case and may be considered by the court. ${ }^{76}$ Where it is not filed, the court should take into account two

70 See Brown v. Allen, supra note 3, at 464, where the Court said: "It is necessary to exercise jurisdiction to the extent of determining by examination of the record whether or not a hearing would serve the ends of justice. Cf. 28 U.S.C. $\$ \S 2244 . "$

71317 U.S. 238 (1942).

72 Ex parte Sharpe, 36 F. Supp. 286 (D.C. Ky. 1941).

73 Sharpe v. Buchanan, 121 F.2d 448 (6th Cir. 1941).

74 See Darr v. Burford, supra note 2, at 204, where the Court stated:

As it would be unseemly in our dual system of government for a federal district court to upset a state court conviction without an opportunity to the state courts to correct a constitutional violation, the federal courts sought a means to avoid such collisions. Solution was found in the doctrine of comity between courts, a doctrine which teaches that one court should defer action on causes properly within its jurisdiction until the courts of another sovereignty with concurrent powers, and already cognizant of the hitigation, have had an opportunity to pass upon the matter.

76 See authorities cited in note 3 supra.

70 28 U.S.C. $\$ 2247$ (Supp. 1952). 
factors in determining this issue. These are (1) the complexity of the issues presented and (2) the adequacy of the state record. ${ }^{77}$

Where the issues presented by a petition are simple and clear, it may facilitate matters greatly if the court orders a hearing to determine them, rather than requiring that a cumbersome record (which probably includes much that involves purely state issues) be produced. On the other hand, where the issues are complex, the district judge should order the record of the state proceedings produced to aid him in ascertaiming the facts. This is a matter governed by the sound discretion of the district judge, and he should take whichever course will best facilitate a rapid determination of the issues with the least inconvenience to the parties.

The state court record must, of course, be adequate if the district judge is to rely upon it. A clearly adequate record is one which shows that a petition was presented to a lower state court, where hearings were held and the facts determined from evidence presented; that an appeal was taken to a state appellate court where the questions certified were considered; and that an exhaustive opinion was written giving the reasons for the decision on appeal. ${ }^{78} \mathrm{~A}$ case in which the state court record is clearly inadequate is one where the state court has summarily dismissed the petition without holding a hearmg or requiring a response, and has issued only a perfunctory order of dismissal. ${ }^{79}$ In the latter case, Justice Frankfurter would appear to require a hearing to determine the facts, ${ }^{80}$ although some of the circuits have not held this view. ${ }^{81}$ In a dictum, the Second Circuit stated that the fact the record does not show the "state court has [not] considered and adjudicated the merits" would justify a dismissal on a record of the type described above as inadequate. ${ }^{82}$ In view of the opinion of Justice Frankfurter in Brown v. Allen, this decision is clearly erroneous.

The adequacy of the state court record may vary between the two extremes outlined above. It is up to the district judge to examine this record

77 Brown v. Allen, supra note 3, at 503.

78 Such as was present in United States ex rel. Smith v. Baldi, 344 U.S. 561,569 (1953); see also Tyson v. Swenson, 198 F.2d 308 (4th Cir. 1952); Bird v. Smith, 175 F.2d 260 (9th Cir. 1949); Haughey v. Snuyth, 170 F.2d 68 (4th Cir. 1948); Stonebreaker v. Smyth, sutpra note 1; Guy v. Utecht, 144 F.2d 913 (8th Cir. 1944). But see Collingsworth v. Mayo, 173 F.2d 695 (5th Cir. 1949).

${ }^{79}$ Such as was present in Uveges v. Pennsylvania, 335 U.S. 437 (1948); House v. Mayo, 324 U.S. 42, 48 (1945); see also, United States ex rel. Almeida v. Baldi, 195 F.2d 815 (3d Cir. 1952), cert. denied, 345 U.S. 904 (1953); United States ex rel. Kennedy v. Burke, 173 F.2d 544 (3d Cir. 1949).

80 Brown v. Allen, supra note 3, at 505.

81 Frazier v. Ellis, 196 F.2d 231 (5th Cir. 1952); Ex parte Adamson, 167 F.2d 996 (9th Cir.), cert. denied, 334 U.S. 834 (1948). In an early case the Ninth Circuit held that such a determination by the state courts was sufficient of itself to justify denying the petition, Sander v. Johnston, 11 F.2d 509 (9th Cir. 1926).

82 Schechtman v. Foster, supra note 3. 
carefully to determine whether it is adequate to show that the state courts have "considered and adjudicated the merits" 83 and to show the methods by which the state courts determined the facts.

\section{Acceptance of Findings of Fact by State Courts}

If the district judge finds the state court record adequate, what weight should he give to findings of fact by that court? Justice Frankfurter states the controlling rule thusly: ${ }^{84}$

When the record of the State court proceedings is before the court, it may appear that the issue turns on basic facts and that the facts (in the sense of a recital of external events and the credibility of their narrators) have been tried and adjudicated against the applicant. Unless a vital flaw be found in the process of ascertaining such facts in the State court, the District Judge may accept their determination in the State proceeding and deny the application.

The use of the words "may accept" would seem to indicate that the district judge may still exercise some discretion as to whether to accept these findings, but Justice Frankfurter has emphasized the "soundness of giving great weight to testimony earlier heard." 85

The positions taken by the circuits prior to Brown v. Allen were largely. based on the following language from Ex parte Hawk: ${ }^{86}$

Where the state courts have considered and adjudicated the merits of his [a petitioner's] contentions, and this Court has either reviewed or declined to review the state court's decision, a federal court will not ordinarily reexamine upon writ of habeas corpus the questions thus adjudicated. (Emphasis supplied.)

An examination of the emphasized portions of the above quotation reveals that a consideration and an adjudication of the merits are required, and many cases have so held. ${ }^{87}$ This squares with Justice Frankfurter's standards. ${ }^{88}$ However, some circuits hold that even where the state court has summarily rejected the claims of a petition, a federal court should not re-examine the merits. ${ }^{89}$ At the other extreme are holdings that although

83 Ex parte Hawk, supra note 13, at 118.

84 Brown v. Allen, supra note 3 , at 506.

85 Ibid. See also, Goodman v. Lainson, 182 F.2d 814, 817 (8th Cir. 1950) ; Gault v. Burford, 173 F.2d 813 (10th Cir. 1949).

86 Supra note 13 , at 118.

87 Frazier v. Ellis, supra note 81 ; United States ex rel. Jackson v. Ruthazer, 181 F.2d 588 (2d Cir. 1950), cert. denied, 339 U.S. 980 (1950); Ex parte Adamson, supra note 81. Contra: United States ex rel. Almeida v. Baldi, supra note 79.

88 Text at supra note 84.

89 Tyson v. Swenson, supra note 78; Anderson v. Eidson, 191 F.2d 989 (8th Cir. 1951); Coggins v. O'Brien, supra note 60; Goodwin v. Smyth, 181 F.2d 498 (4th Cir. 1950); Bird v. Smith, supra note 78; Schechtman v. Foster, supra note 3 ; Haughey v. Smith, supra note 78; Mart v. Lainson, 169 F.2d 1016 (8th Cir. 1948); Bernard v. Brady, 164 F.2d 881 (4th Cir. 1947), cert. denied, 332 U.S. 856 (1948) ; Stonebreaker v. Snyth, supra note 1; Guy v. Utecht, supra note 78. 
a full adjudication has occurred in the state courts, a plenary hearing is required, ${ }^{90}$ or that the district court can hold a plenary hearing even in the absence of special circumstances. ${ }^{91}$ Both of these extremes appear erroneous.

The latest statement of the Supreme Court on this question is contained in United States ex rel. Smith v. Baldi, where (in rejecting petitioner's contention that a plenary hearing should have been held) the following language of the district court was quoted with approval: ${ }^{02}$

[Not] unless special circumstances prevail, should the lowest federal court reverse the highest state court in cases where the constitutional issues have been disposed on the merits by the highest state court in an opinion specifically setting forth its reasons that there has been no denial of due process of law, and where the record before the state court and the allegations in the petition for the writ before the federal court fail to disclose that the state in its prosecution departed from the constitutional requirements.

The "special circumstances" of this case or the extraordinary situation envisaged by the Hawk case are probably those situations, referred to by Justice Frankfurter, in which the fact finding process of the state courts contains a vital flaw..$^{93}$ Thus it is the duty of the district judge, when he has an adequate state court record before him, to examine the fact finding process. If no fault is found therein, the judge should give the facts found by the state court great and almost conclusive weight.

\section{Mixed Questions of Law and Fact}

Not all factual determinations by state courts may be accepted by the district court, in the opinion of Justice Frankfurter. The "so-called mixed questions or the applications of constitutional principles to the facts as found leave the duty of adjudication with the federal judge." ${ }^{04}$ Examples of such questions are : whether a confession is voluntary or involuntary; ${ }^{95}$ whether counsel was necessary to insure a fair trial; ${ }^{36}$ whether a trial has

${ }^{00}$ Collingsworth v. Mayo, supra note 78; McGarty v. O'Brien, 188 F.2d 151 (1st Cir.), cert. denied, 341 U.S. 928, 951 (1951) (semble); McCrea v. Jackson, stipra note 39 (dictum).

${ }^{91}$ United States ex rel. Daverse v. Hohn, 198 F.2d 934 (3d Cir. 1952), cert. dcnied, 344 U.S. 913 (1953); United States $e x$ rel. Smith v. Baldi, 192 F.2d 540 (3d Cir. 1951), aff'd., 344 U.S. 561 (1953).

92 Sutpra note 78 at 569-570. Quoting from 96 F. Supp. 100, 103.

93 See Collingsworth v. Mayo, supra note 78; Schechtman v. Foster, supra note 3.

94 Brown v. Allen, supra note 3, at 507.

95 See Stroble v. California, 343 U.S. 181, 190 (1952). But see Lisenba v. California, 314 U.S. 219, 238 (1941) where the Court stated that where the evidence as to the voluntariness of a confession is conflicting the determination of the state courts would be accepted "unless it is so lacking in support in the evidence that to give it effect would work that fundamental unfairness which is at war with due process."

${ }^{96}$ Sce Powell v. Alabama, 287 U.S. 45 (1932). 
been dominated by threats of, or actual, mob violence; ${ }^{97}$ or whether by fraud, collusion, trickery, or subornation of perjury by the state's representatives, one was deprived of that fair trial required by due process. ${ }^{98}$ As stated by Justice Frankfurter: ${ }^{99}$

[I]t is for the federal judge to assess on the basis of such historical facts [found by the State courts] the fundamental fairness of a conviction... in the circumstances. Although there is no need for the federal judge, if he could, to shut his eyes to the State consideration of such issues, no binding weight is to be attached to the State determination.

The circuits have not always adopted this view. Indeed some have indicated that determinations on questions of federal constitutional law made by a state court, if fairly and honestly made to the best of the court's ability, may not be questioned by the federal courts, even though erroneous. ${ }^{100}$ It may even be that those cases relying on Ex parte Harek were in some part imbued with this thought. ${ }^{101}$

These cases are clearly erroneous if Justice Frankfurter's views are to be considered authoritative. However, this does not mean that a plenary hearing is necessary to decide these mixed questions, ${ }^{102}$ but merely that the district judge must examine the historical or "pure" facts as found by the state court and apply the federal law to the situation as it is thus shown, without giving state decisions as to federal law conclusive effect.

\section{Successive Applications}

Assuming that the circumstances outlined in the foregoing are most favorable to the prisoner, he may yet be faced with an insurmountable obstacle if a similar application for habeas corpus has been denied him by a federal judge or court. ${ }^{103}$ Of course the doctrine of res judicata has no application to habeas corpus proceedings; ${ }^{104}$ but under Section 2244, Title 28, United States Code the court to which the application is presented may refuse to entertain it in certain cases if there has been a prior refusal of relief. ${ }^{105}$

\footnotetext{
97 See Moore v. Dempsey, supra note 65.

98 See Mooney v. Holohan, 294 U.S. 103 (1935).

89 Brown v. Allen, supra note 3, at 507-508. See also, United States ex rel. Kennedy v. Burke, supra note 79.

100 Schechtman v. Foster, sttpra note 3; Guy v. Utecht, sttpra note 78.

101 See cases cited supra note 87.

102 See United States ex rel. Smith v. Baldi, supra note 78, where one of the questions was the adequacy of the representation of counsel in a capital case and where the Court held that no plenary hearing was necessary.

10328 U.S.C. $\$ 2244$ (Supp. 1952).

104 Salinger v. Loisel, supra note 10.

10528 U.S.C. $\$ 2244$ (Supp. 1952):

No circuit or district judge shall be required to entertain an application for a writ of habeas corpus to inquire into the detention of a person pursuant to a judgment of a court ... of any State, if it appears that the legality of such
} 
While the doctrine that the making of repeated applications for a writ of habeas corpus based on the same grounds is an abuse of the writ and should not be permitted has long been recognized by the federal courts, ${ }^{100}$ it was not clearly enunciated until Salinger $v$. Loisel. There the Supreme Court held that, although the doctrine of res judicata does not extend to decisions in habeas corpus proceedings, a prior refusal could be considered by the court receiving the second application and could justify a refusal of the second application. ${ }^{107}$ The factor of "no new ground" found in Section 2244 was added by Waley $v$. Johnston. ${ }^{108}$

The Reviser's Note indicates that Section 2244 was not intended to change existing practice, but only to make specific the rules adopted by the courts to prevent successive "nuisance" applications for the writ. ${ }^{100}$ Thus, one must turn to the cases to determine the meaning of the section.

In a great majority of the cases where a court is presented with successive applications, the result has been a refusal to entertain them. ${ }^{110}$ Where a petition is clearly repetitious and the prior refusal was upon the merits, this is clearly correct. In determining whether a petition is repetitious and whether there has been a prior determination on the merits of the question presented, the court may take judicial notice of the records of the prior proceedings. ${ }^{111}$ It is not necessary to have these records brought formally into court. ${ }^{112}$

In Wong Doo v. United States, decided the same day as Salinger $v$.

detention has heen determined by a judge or court of the United States on a prior application for writ of habeas corpus and the petition presents no new ground not theretofore presented and determined, and the judge or court is satisfied that the ends of justice will not be served by such inquiry.

106 See Ex parte Cuddy, 40 Fed. 62 (S.D. Cal. 1889).

107 Salinger v. Loisel, supra note 10, at 230-231.

108316 U.S. 101, 105 (1942). See also, United States ex rel. McCann v. Adams, 320 U.S. 220 (1943).

10928 U.S.C. $\S 2244$ (Supp. 1952) (revisor's notes).

110 Price v. Johnston, 161 F.2d 705 (9th Cir. 1947), reversed, 334 U.S. 266 (1948); Ex parte Farrell, 189 F.2d 540 (1st Cir.), cert. denied, Farrell v. O'Brien, 342 U.S. 839 (1951); Wells v. United States, 158 F.2d 833 (5th Cir.), cert. denied, 331 U.S. 852 (1947); Garrison v. Johnston, 151 F.2d 1011 (9th Cir. 1945), cert. denied, 328 U.S. 840 (1946) ; Swihart v. Johnston, 150 F.2d 721 (9th Cir. 1945), cert. denied, 327 U.S. 789 (1946); Rookard v. Huff, 145 F.2d 708 (D.C. Cir. 1944) ; Burall v. Johnston, 62 F. Supp. 825 (N.D. Cal. 1945), Ex parte Roberts, 61 F. Supp. 864, 868 (W.D. Va. 1945); United States ex rel. Mitchell v. Hiatt, 59 F. Supp. 826 (M.D.Pa.), aff'd., 151 F.2d 190 (3d Cir. 1945); United States ex rel. Bowen v. Johnston, 58 F. Supp. 208, 209 (N.D. Cal. 1944), aff'd and adopted, 146 F.2d 268 (9th Cir. 1944), cert. denied, 324 U.S. 876 (1945) ; Coates v. Lawrence, 46 F. Supp. 414, 421 (S.D. Ga. 1942), aff'd and adopted, 131 F.2d 110 (5th Cir. 1942), cert. denied, 318 U.S. 759 (1943); Wheeler v. Kaiser, 45 F. Supp. 937, 939 (W.D. Mo. 1942); Mothershead v. King, 37 F. Supp. 210, 213 (W.D. Mo. 1941).

111 Dorsey v. Gill, 148 F.2d 857, 869-870 (D.C. Cir.), cert. denied, 325 U.S. 890 (1945); Rookard v. Huff, supra note 110.

112 Ibid. 
Loisel, the Supreme Court held that where the matters could have been presented at the first hearing, the court, in its discretion, may dismiss the subsequent petition because of the prior refusal of relief. ${ }^{13}$ There, the ground for the second application was set up, with another, in the first application. The evidence to support this ground was withheld by the petitioner, without excuse, for use on a second attempt if the first failed. In reliance on this case, several circuits have held that where the petitioner knew of the facts at the time of a former hearing, the district court could dismiss the second application. ${ }^{114}$

Federal courts must be careful not to use Section 2244 as a means of avoiding their duty to "dispose of the matter as law and justice require."115 Where the prior refusal was upon some procedural ground, such as a failure to exhaust state remedies, this section ought not to be invoked. ${ }^{116}$ In applying the doctrine of the Wong Doo case, courts must keep in mind the limitations upon that doctrine imposed by Price v. Johnston. ${ }^{117}$ There the Court held that the respondent must make the claim that the prisoner has abused the writ with clarity and particularity in its return to the order to show cause. "Once a particular abuse has been alleged, the prisoner has the burden of answering that allegation and of proving that he has not abused the writ. If the answer is inadequate, the court may dismiss the petition without further proceedings. But if there is a substantial conflict, a hearing may be necessary to determine the actual facts." 118 Hence, it is not sufficient for the judge to determine that the petitioner knew of the matters alleged at the time of making the former application and thus to refuse to permit the petitioner to file a subsequent application. In such a situation he must permit the application to be filed; and when the respondent alleges such an abuse, the judge must require an answer from the petitioner explaining away the apparent abuse. ${ }^{119}$ If the answer is not satisfactory, then (and only then) may the judge dismiss the petition. Such a formal procedure does not seem necessary where the matters were determined in a prior application and no new grounds are presented in the subsequent application. In this situation the court may take judicial notice of the records of the

113265 U.S. 239 (1924).

114 Price v. Johnston, supra note 110; Garrison v. Johnston, supra note 110; Swihart v. Johnston, supra note 110; Pope v. Huff, 141 F.2d 727 (D.C. Cir. 1944); United States ex rel. Bruno v. Reimer, 103 F.2d 341, 342 (2d Cir. 1939) (dictum).

11528 U.S.C. $\$ 2243$ (Supp. 1952).

116 Note the qualification contained in $\$ 2244:$ ", . . and the judge or court is satisfied that the ends of justice will not be served by such inquiry."

117334 U.S. 266 (1948).

118 Id. at 292 .

110 Lynch v. Swope, 172 F.2d 301, 302 (9th Cir. 1949) ; see McDonald v. Swope, 79 F. Supp. 30 (Denman, C.J., 9th Cir. 1948), reversed, Swope v. McDonald, 173 F.2d 852 (9th Cir. 1949), cert. denied, 337 U.S. 960 (1949). 
prior proceedings without having them brought formally into the court. ${ }^{120}$ However, the prisoner is still entitled to an opportunity to explain away the apparent abuse. There may have been a change of circumstances since the prior application which negates the effect of the prior determination, ${ }^{121}$ to cite only one possibility.

These standards of Justice Frankfurter, if followed by the lower federal courts, will do much to prevent conflicts between the federal and state systems. The state courts have the first opportunity to try the issues presented under the exhaustion requirement. If they grant an adequate hearing on these issues, their determinations will be given great weight. In this type of case the only "review" of the state court decision will be on questions of federal law-questions which the federal court takes as a court of original jurisdiction and not as an appellate court.

Thus the burden is placed squarely upon the states. If they wish to lessen federal "interference" with their criminal process, they must grant a hearing where facts are alleged which, if true, establish a violation of the prisoner's constitutional rights. If they fail to do this, the prisoner has been denied an opportunity to prove his charges and the federal courts must step in, not only applying the federal law but also determining the facts to which that law is to be applied. The State of Washington has enacted a statute which should have the effect of making many determinations on habeas corpus in that state's courts final. This statute reads as follows: ${ }^{122}$

In the consideration of any petition for a writ of habeas corpus by the supreme court, whether in an original proceedimg or upon an appeal, if any federal question shall be presented by the pleadings, it shall be the duty of the supreme court to determine in its opinion whether or not the petitioner has been denied a right guaranteed by the Constitution of the United States.

While this statute does not require a hearing, it does seem to require the Washington Supreme Court to write an opinion giving the reasons for its decisions. In many cases where a hearing was held and the facts determined, such an opinion may be very persuasive on the federal questions.

In conclusion, it should be pointed out that there is no danger of a wholesale opening of the prison gates by the federal courts. This is shown by statistics contained in Justice Frankfurter's opinion in Brown v. Allen. There it is shown that out of 3,702 applications for habeas corpus studied (including applications by both state and federal prisoners), the writ was issued in only sixty-seven cases, and only a small number of these sixtyseven writs resulted in the release of the prisoner. ${ }^{123}$

120 Rookard v. Huff, supra note 110.

121 Stewart v. Overholser, 186 F.2d 339 (D.C. Cir. 1950).

122 WASE. REv. CODE $\S 7.36 .140$ (1952).

123 Supra note 3 at 498 . 